$\begin{array}{ll} & \text { Etnográfica } \\ \text { etnográfica } & \text { Revista do Centro em Rede de Investigação em }\end{array}$

Antropologia

vol. 11 (1) | 2007

Vol. 11 (1)

\title{
Luís Cunha, Memória Social em Campo Maior
}

\section{Eduarda Rovisco}

URL: https://journals.openedition.org/etnografica/1964

DOI: 10.4000/etnografica.1964

ISSN: 2182-2891

\section{Editora}

Centro em Rede de Investigação em Antropologia

\section{Edição impressa}

Data de publição: 1 maio 2007

Paginação: 273-275

ISBN: 0873-6561; E-ISBN 2182-2891

ISSN: 0873-6561

\section{Refêrencia eletrónica}

Eduarda Rovisco, «Luís Cunha, Memória Social em Campo Maior», Etnográfica [Online], vol. 11 (1) | 2007, posto online no dia 26 setembro 2012, consultado o 12 fevereiro 2022. URL: http://

journals.openedition.org/etnografica/1964 ; DOI: https://doi.org/10.4000/etnografica.1964

Este documento foi criado de forma automática no dia 12 fevereiro 2022.

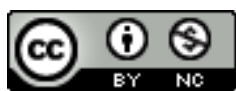

Etnográfica is licensed under a Creative Commons Attribution-NonCommercial 4.0 International License. 


\title{
Luís Cunha, Memória Social em Campo Maior
}

\author{
Eduarda Rovisco
}

\section{REFERÊNCIA}

Luís Cunha, Memória Social em Campo Maior, Lisboa, Publicações Dom Quixote, 2006.

1 Esta obra, que corresponde à edição de uma tese de doutoramento em Antropologia, parte de um trabalho de campo realizado em Campo Maior entre Dezembro de 1997 e Outubro de 1998. A data de realização deste terreno deve ser retida por coincidir com um momento charneira na raia luso-espanhola. Por ter decorrido poucos anos após a abertura da fronteira, esta pesquisa implicou uma reflexão sobre o seu impacto nos processos de construção da memória e identidade colectiva, mas permitiu ainda a colecção de um conjunto significativo de testemunhos orais que viabilizaram o tratamento da memória da Guerra Civil de Espanha num capítulo autónomo. Por outro lado, este terreno situa-se num momento de detonação da produção antropológica sobre a fronteira luso-espanhola.

2 Memória Social em Campo Maior alicerça-se sobre uma análise dos processos de articulação entre memória, espaço e tempo potenciados pela fronteira. Dividindo-se em seis capítulos, nos primeiros três são abordadas questões metodológicas, categorias analíticas como tempo, espaço, memória e fronteira, bem como a especificidade da fronteira em Campo Maior e das culturas de fronteira. São, contudo, os capítulos seguintes que merecem relevo, uma vez que é neles que tem lugar o tratamento de espaço, tempo e memória enquanto objectos empíricos.

3 No capítulo 4, intitulado “Espaços, práticas e representações. A memória e a sua recomposição", Luís Cunha procede à análise dos modos de inscrição da memória no espaço e no tempo. No espaço, através do mapeamento dos lugares de memória em Campo Maior e da sua análise enquanto signos que remetem para valores específicos ou para clivagens sociais. No que concerne ao tempo, com base nos discursos dos seus 
informantes, o autor distingue dois tempos: o tempo do "antes", marcado pelo domínio de grandes proprietários rurais - com Dr. Gama à cabeça, o mais proeminente latifundiário da vila - vs o tempo do "agora", marcado pelo poder dos industriais da torrefacção do café - emblematizado por Rui Nabeiro, que controla agora as regras de acesso ao trabalho ao empregar "mais de $50 \%$ da força produtiva do concelho" (p. 143). A sucessão destes dois "senhores da vila" consiste assim na substituição de uma elite de latifundiários por uma elite de industriais descendentes de contrabandistas, substituição esta que pode ser lida como o "desagravo dos humildes sobre os poderosos" (p. 327), e que concorre para a imagem de herói que Rui Nabeiro adquiriu nesta vila. Neste capítulo deve ser destacada a evocação do patrocinato feita pelo autor. Possivelmente não caberia no âmbito desta obra uma análise mais detalhada do patrocinato, contudo revelar-se-ia seguramente fecunda.

0 capítulo 5, dedicado à memória do contrabando, não tendo a pretensão de traçar o longo itinerário desta actividade, refere alguns aspectos que se prendem com o estabelecimento, evolução e policiamento de barreiras alfandegárias, focalizando a fronteira enquanto espaço de oportunidade para as populações que nela vivem e o contrabando como "a seiva que alimentou a relação" (p. 171) entre os vizinhos dos dois lados da raia. Desvendando as lógicas de organização desta actividade em Campo Maior, são estabelecidos dois marcos de mudança nos processos de organização desta actividade: 1) no fim da II Guerra Mundial, o café torna-se a mercadoria mais contrabandeada, uniformizam-se as práticas e assalaria-se a mão-de-obra; 2) na década de 70, o transporte ilegal de café para Espanha passa a ser feito em camiões, diminuindo assim o número de homens implicados no contrabando.

5 Nesta análise da memória do contrabando em Campo Maior, são destacados pelo autor alguns aspectos que devem ser valorizados. Tanto a codificação dos modos de narrar o contrabando, que lhes imprime um carácter consensual, exacerbando as dimensões de aventura e estratégia, quanto a permanente avaliação moral do comportamento de autoridades e de contrabandistas face à ausência de avaliação moral da actividade em si, resulta, segundo o autor, do facto do contrabando ter adquirido uma "legitimidade simbólica" com a abertura das fronteiras e com o êxito da indústria de torrefacção de café gerada pelo contrabando.

6 Estabelecendo um paralelo entre a proposta de análise elaborada por Comas d'Argemir sobre o tabaco contrabandeado em Andorra, enquanto facto social total (Comas d'Argemir, 1999), Luís Cunha afirma: "devemos sublinhar que também em Campo Maior o café se constitui como 'facto social total', quer dizer, elemento articulador de várias dimensões sociais locais, desde a política à economia, entroncando nele também referenciais identitários, tão significativos na vila como o clube de futebol ou as Festas do Povo" (p. 239).

7 Ao contrário da consensual memória do contrabando, a memória da Guerra Civil de Espanha, tratada no 6.ำ último capítulo, surge dicotomizada pela clivagem social, não sendo a sua evocação tão espontânea, uma vez que remete para um universo de silêncio e trauma. $\mathrm{O}$ núcleo da memória da Guerra consiste na memória sobre os refugiados que, como refere o autor "eram a própria guerra entrando no quotidiano da vila" (p. 259). Muitos destes refugiados, que começaram a chegar a Campo Maior em Agosto de 1936 na sequência dos acontecimentos de Badajoz, foram presos pelas autoridades portuguesas e concentrados na prisão da vila e nos celeiros da Federação de Produtores de Trigo. Muitos deles terão sido entregues às forças nacionalistas e executados. 
8 À invisibilidade decorrente da situação de clandestinidade das pessoas que fugiram de Espanha por razões políticas e que conseguiram permanecer em Campo Maior escondidas em sótãos ou abrigos para animais, contrapõe-se a visibilidade de um contingente de pessoas que diariamente atravessava a fronteira em busca de alimentos. A miséria extrema destas pessoas, o grupo de Duro refugiado em Referta de Ouguela, os bombardeamentos de Badajoz, os fuzilamentos na praça de touros, a que assistiram portugueses, a violência do exército de África, a polarização ricos vs pobres, constituem alguns dos temas centrais da memória da Guerra trabalhada pelo autor.

o funcionamento da memória sobre a Guerra Civil de Espanha não constitui o tema central desta obra. $\mathrm{O}$ autor assume, de resto, o "carácter fragmentário" do capítulo, bem como a sua renúncia "ao desejo de uma abordagem mais profunda" (p. 254). Todavia, o tratamento de alguns dos temas acima referidos teria ganho com uma recolha mais exaustiva de testemunhos e com a consulta de outro tipo de materiais. No que concerne, por exemplo, à análise da memória sobre o grupo de Duro, adjectivado de "abusador" e "cruel", teria sido oportuno investigar a hipótese de esta adjectivação negativa poder decorrer de processos de silenciamento e revisionismo impostos de fora (veja-se, sobre este assunto, AA. VV., 2004, O Cambedo da Raia. Solidariedade galegoportuguesa Silenciada. Asociación Amigos da República).

Defendendo que "aquilo que hoje distingue comunidades de fronteira como Campo Maior, não são já as referências culturais do presente, mas aquelas que a memória produz" (p. 319), Memória Social em Campo Maior constitui um valioso contributo para o conhecimento da fronteira luso-espanhola, provando a persistência e reafirmação da fronteira através da memória.

\section{AUTORES}

\section{EDUARDA ROVISCO}

Centro de Estudos de Antropologia Social (ISCTE), Bolseira da FCT 